\title{
Pelatihan food photography bagi kelompok UKM kuliner Kecamatan Rappocini Kota Makassar
}

\author{
Siti Fuadillah", Andi Annisa Amalia, Khilda Wildana Nur \\ Prodi Arsitektur, Fakultas Teknik \\ Universitas Muhammadiyah Makassar \\ Email Korespondensi: * sitifuadillah@ unismuh.ac.id
}

Received November 5, 2020; Revised March 19, 2021; Accepted March 23, 2021

\begin{abstract}
Abstrak
Usaha makanan atau kuliner saat ini menjadi tren dan gaya hidup terutama di kota-kota besar seperti Jakarta, Bandung dan Surabaya, Makassar dan kota-kota besar lainnya. Makanan merupakan elemen kuat dalam menunjukkan dan memperkenalkan daerah maupun sebuah usaha kuliner. Hal ini mendasari tren perkembangan fotografi makanan atau food photography. UKM Kuliner Kecamatan Rappocini saat ini hanya mengemas produk kulinernya dengan sederhana, mengambil sampel foto di sosial media maupun internet yang bukan merupakan foto produk secara original. Sehingga pembeli kurang tertarik dengan kuliner tersebut. Hal ini mendasari kegiatan pengabdian masyarakat dalam Pelatihan food photography bagi pelaku usaha tersebut sebagai solusi pengembangan UKM kuliner yang ada di Rappocini. Metode pelatihan adalah melakukan sosialisasi tentang kegiatan dan pembekelan materi mengenai Langkah-langkah pembuatan food photography kemudian peserta melakukan praktek langsung dan penilain hasil pemotretan dari sampel makanan yang disiapkan. Target luaran yang diharapkan adalah peningkatan kapasitas pelaku UKM Kuliner, peningkatan kapasitas dalam promosi dan pemasaran UKM dari food photography sehingga dapat menjadi UKM yang lebih professional dan mandiri.
\end{abstract}

Kata Kunci: usaha makanan; food photography; pelatihan; promosi dan pemasaran

Abstract
Recently culinary businesses have become trend and life style especially in Jakarta, Bandung, Surabaya, Makassar and other big cities. Food is essential element that shows and represents local and culinary business. This issue enables food photography in culinary sector. Small Micro Medium Enterprises of culinary in District of Rappocini only pack their culinary simply, take photo sample from either social media or internet that does not present original food product itself, so the sellers seem to be less interested to purchase those foods. The community services in food photography for business entrepreneurs become a solution for development of small micro medium enterprises in District of Rappocini. The workshop method includes conducting socialization about program and training of food photography then participants practice and assess the result of the provided sample foods. The expected outcomes are to improve skill capacity of culinary business entrepreneurs, to develop promotion and marketing of small micro medium enterprises as a result of food photography training. Hence, the small micro medium enterprises can be more professional and more independent.

Keywords : businesses culinary; food photography; practice; promotion and marketing

\section{PENDAHULUAN}

Pemberdayaan usaha mikro, kecil dan menengah menjadi strategis sebagai sektor penggerak kegiatan ekonomi masyarakat dan sekaligus tumpuan sumber pendapatan Sebagian masyrakat yang bergerak di sektor informal. Dalam kurun 10 tahun terakhir di Kota Makassar eksistensi dan peran UKM sangat besar dalam berkontribusi menyerap tenaga kerja pada dunia usaha. Usaha Kecil dan Menengah disingkat UKM adalah sebuah istilah yang mengacu ke jenis usaha kecil. Menurut Keputusan Presiden RI no. 99 tahun 1998 pengertian Usaha Kecil adalah: "Kegiatan ekonomi rakyat yang berskala kecil dengan bidang usaha yang secara mayoritas merupakan kegiatan usaha kecil dan perlu dilindungi untuk mencegah dari persaingan usaha yang tidak sehat." Usaha Mikro, Kecil dan Menengah (UMKM) di berbagai negara termasuk di Indonesia merupakan salah satu penggerak perekonomian rakyat yang tangguh. Hal ini karena kebanyakan para pengusaha mikro, kecil dan menengah berangkat dari industri keluarga atau rumahan [1].

Kemampuan UKM dalam menyerap tenaga kerja dan meningkatkan nilai tambah semakin tinggi. Pada tahun 2009, nilai tambah yang dihasilkan UKM di Indonesia sebesar 2.993.151 Milyar dan jumlah UKM mencapai 52.7 juta atau 99,9\% dari total perusahaan yang ada di Indonesia. Dalam hal menciptakan pekerjaan, 
UKM di Indoensia mampu menyediakan 96.2 juta tenaga kerja atau 97.3\% dari total tenaga kerja [2]. Usaha mikro, usaha kecil dan usaha rumah tangga terdapat di semua kategori lapangan usaha ekonomi selain kategori lapangan usaha pertanian tanpa harus mempunyai jenjang Pendidikan maupun keahlian khusus namun pada era revolusi industry 4.0 saat ini, yang terpenting adalah keterampilan dan kreativitas dalam mengolah makanan hingga metode memasarkan terutama secara digital. Makassar merupakan salah satu kota besar di Indonesia dan merupakan living room Kawasan Timur Indonesia, sehingga perkembangan UKM yang pesat dengan gaya hidup konsumtif menuntut UKM kuliner harus lebih cekatan dalam menangkap peluang dan tantangan pasar tersebut.

Bisnis makanan yang ada di Kota Makassar hampir mewarnai seluruh kecamatan dengan beragam ciri khas dan jenis makanan yang ditawarkan. Bisnis makanan adalah bisnis yang tidak akan pernah redup karena cepat habis dan frekuensi kebutuhan tidak pernah berhenti karena merupakan kebutuhan pokok manusia. Hal tersebut merupakan pendorong sektor kuliner berkembang pesat terutama yang mudah dipesan sistem online, sehingga membutuhkan kreativitas para pelaku UKM kuliner untuk menjajakan produknya secara menarik di sosial media maupun terutama melalui aplikasi online seperti grab food, go food dan sejenisnya. Fakta bahwa perkembangan internet telah mencapai kebutuhan manusia yang sangat mendasar membuat UKM dapat memperluas bisnis mereka di seluruh dunia. Mereka, tentu saja, diharuskan untuk memahami beberapa keterampilan dasar dan keterampilan dasar untuk bertahan hidup di bisnis internet, seperti pangsa pasar elektronik, etika e-market, dan iklan e-market [3]. Keberlangsungan bisnis di sektor UKM tidak terlepas dari strategi berorientasi pasar dan inovasi produk terhadap keunggulan bersaing, mengelola bisnis pasar tantangannya pada penciptaan produk unggulan, baik berhadapan dengan pebisnis franchise brand internasional, franchise nasional/daerah maupun dengan sesama entitas pebisnis lokal [4].

Kota besar seperti Makassar sudah banyak usaha Kuliner yang ada termasuk UKM kecil yang bergerak dibidang Kuliner. Usaha Kecil dan Menengah disingkat UKM adalah sebuah istilah yang mengacu ke jenis usaha kecil. Menurut Keputusan Presiden RI no. 99 tahun 1998 pengertian Usaha Kecil adalah: "Kegiatan ekonomi rakyat yang berskala kecil dengan bidang usaha yang secara mayoritas merupakan kegiatan usaha kecil dan perlu dilindungi untuk mencegah dari persaingan usaha yang tidak sehat." Usaha Mikro, Kecil dan Menengah (UMKM) di berbagai negara termasuk di Indonesia merupakan salah satu penggerak perekonomian rakyat yang tangguh. Hal ini karena kebanyakan para pengusaha mikro, kecil dan menengah berangkat dari industri keluarga atau rumahan.

Banyaknya UKM dengan jenis yang sama membuat UKM tidak bisa melakukan perubahan atau inovasi besar dalam jenis usaha dan produk yang ditawarkan, karena Sebagian besar UKM hanya mengikuti arus bisnis justru menjadi penghambat perkembangannya. Dalam perkembangan daya saing dalam proses usaha, perlu ada pembeda agar dapat bersaing dengan usaha lainnya, oleh karena itu dibutuhkan strategi seperti pendekatan penguasaan ruang pasar yang tidak ramai diperebutkan dimana menciptakan demand baru sebagai market space yang belum diketahui dan tersentuh oleh UKM secara umum [5].

Untuk meningkatkan kemampuan pelaku UMKM dalam memasarkan produknya melalui online, diperlukan foto produk untuk dipublikasikan sehingga calon konsumen mengetahui bentuk atau rupa produk yang ditawarkan. Maka dari itu, diperlukan kemampuan foto dan editing foto agar gambar produk dalam foto terlihat lebih menarik. Dengan demikian diharapkan foto-foto produk tersebut memiliki nilai komersial sekaligus menampilkan branding produk yang dipasarkan [13]. Penyajian fotografi makanan sangat penting akan adanya unsur estetetis dalam visual. Sebuah foto dapat berperan sebagai media penyampaian pesan yang efektif untukmemperoleh kepercayaan meyakinkan konsumen terhadap produk [6].

Adapun UKM yang akan kami lakukan pengabdian yaitu Kelompok UKM kecil yang bergerak dibidang usaha kuliner yang tengah merintis di Kecamatan Rappocini. Umkm yang bergerak di bidang kuliner di kecamatan rappocini ada kurang lebih 30 tersebar di 11 kelurahan yang ada di kecamatan rappocini. Kelompok UMKM bidang kuliner ini beragam mulai dari makanan berat, makanan ringan, dan juga ada berupa bumbu masakan. UMKM ini banyak dibantu dari PKK Kecamatan Rappocini. Produksi UKM ini berskala rumahan dengan packing yang sederhana tetapi potensi besar untuk dipasarkan.

UKM kuliner di Kecamatan Rappocini pada tahun 2017 meraih juara pertama pada lomba UKM antar Lorong yang diselenggarakan oleh Dinas Koperasi dan UMKM Kota Makassar. Lomba tersebut diikuti oleh 15 kecamatan se Kota Makassar dan Lorong 4 di Jalan Rapocini Raya. UKM Lorong tersebut dikelola oleh masyarakat, selain kuliner terdapat pula UKM kerajinan. UKM kuliner tersebut menjual jenis kue tradisional jenis putu yang berlokasi di rumahnya sendiri. Selain itu, produk UKM kuliner Rappocini seperti buras dan ketupat, rempah-rempah dan bumbu yang berasal dari Kelurahan Tidung juga dipasarkan di kuliner kanrerong Lapangan Karebosi di tahun 2018, bahkan ada juga yang sampai di supermarket seperti bumbu rawon, Sop Konro dan Pallu Basa yang merupakan makanan khas Makassar.

Salah satu usaha yang telah dilakukan oleh PKK Kecamatan Rappocini adalah mengikutkan kegiatan PKK skala kecamatan,Kota hingga tingkat Provinsi ataupun mengikutkan pada acara Kecamatan atau Lombalomba UMKM yang ada di Kota Makassar seperti Lomba UKM Lorong yang diadakan Dinas Koperasi dan UMKM Kota Makassar. Yang baru-baru mereka lakukan adalah Lomba UMKM tingkat Kecamatan yang dinilai langsung oleh Kepala Dinas Koperasi Kota Makassar. 


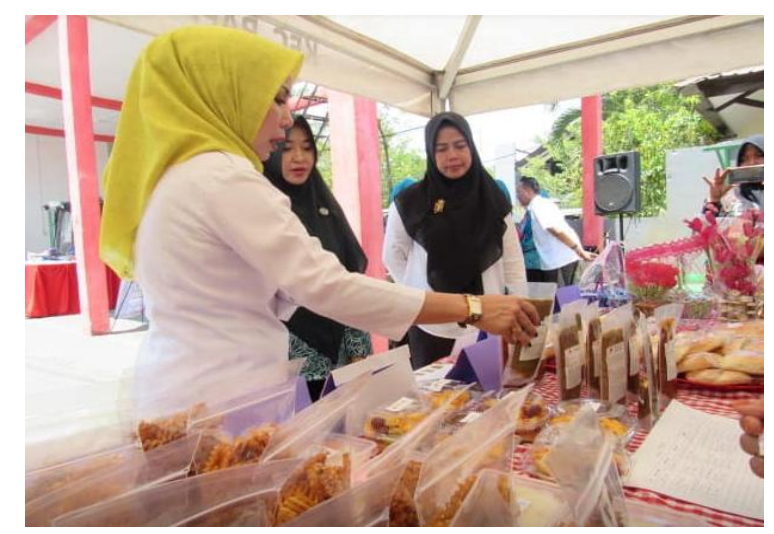

Gambar 1. Kegiatan Pameran yang diikuti UMKM di Kecamatan Rappocini

Permasalahan Kelompok UKM ini lebih banyak dari segi pemasaran karena mereka hanya mengemas dengan sederhana dan tampilan foto yang biasa dan hanya mengambil gambar makanan yang ada di internet. Sehingga pembeli kurang yakin dengan kuliner yang mereka buat. Padahal perkembangan teknologi informasi membawa pengaruh dalam teknologi pemotretan. Jika dulu memotret membutuhkan kemampuan khusus dan butuh proses yang Panjang, saat ini penggunaan teknologi kamera pada perangkat telepon genggam menjawab hal tersebut dan mengubah persepsi terhadap fotografi. Fotografi dapat menceritakan banyak hal tanpa harus ada banyak kata-kata. Fotografi dapat diartikan dengan makna yang berbeda-beda berdasarkan relevansi daripada target audience [7]. Foto makanan dapat diunggah dalam bentuk hasil foto berkualitas visual menarik dan berbeda-beda sesuai dengan kualitas handphone tersebut maupun Teknik pengambilannya. Foto makanan diunggah dalam bentuk hasil foto dengan kualitas visual yang berbeda-beda. Jenis makanan yang disebarkan melalui foto ini pun beraneka macam dan menghasilkan representasi yang beragam pula [8].

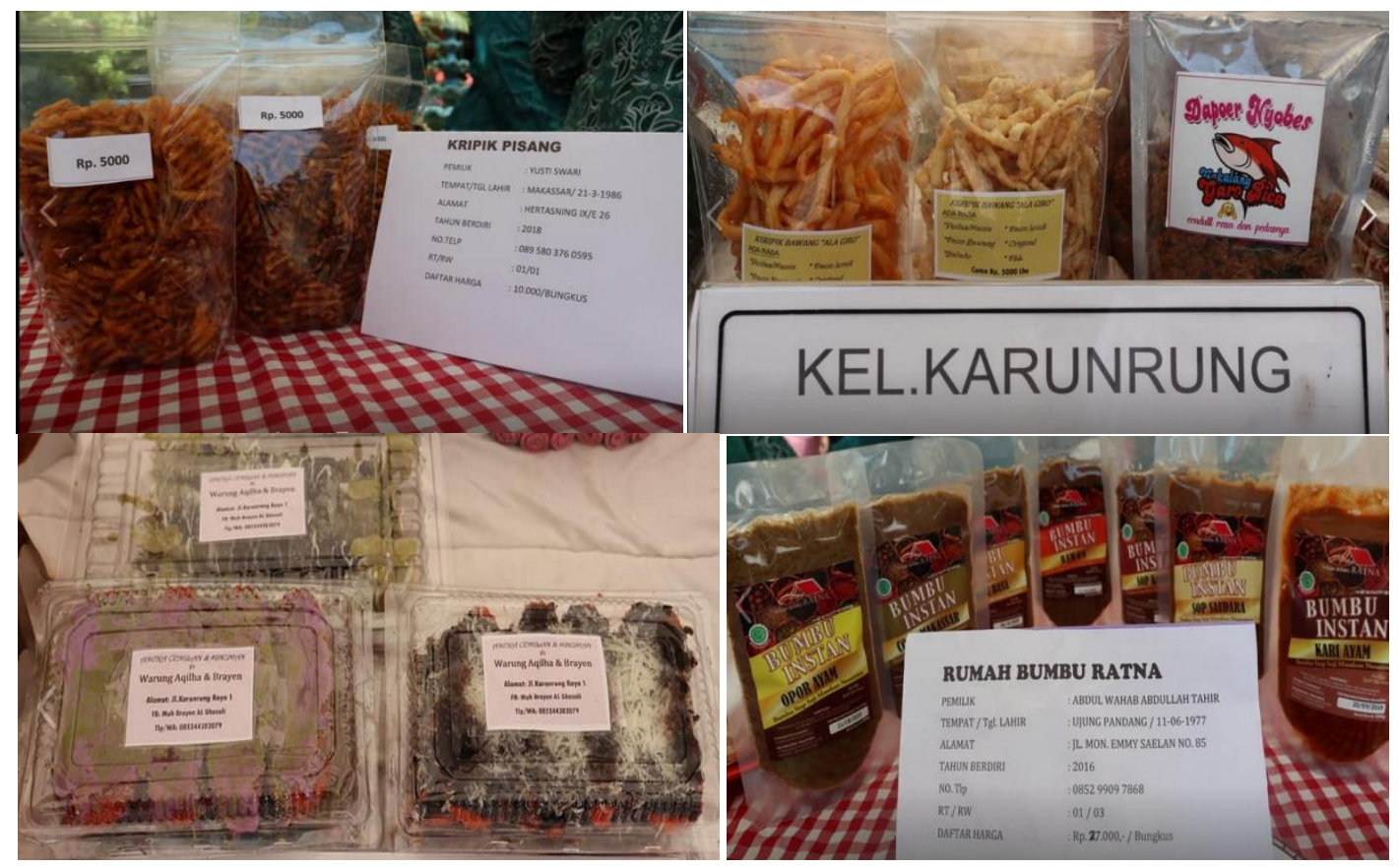

Gambar 2. Beragam Produk UKM Kecamatan Rappocini

Food Photography adalah sebuah cabang seni fotografi yang bertujuan untuk mengabadikan segala macam bentuk dari makanan yang disetting sedemikian rupa sehingga mampu tergambarkan lezatnya makanan tersebut tanpa bercerita dan hanya gambar yang berbicara [9]. Food Photography merupakan salah satu jenis still life Photography, juga termasuk commercial photography. Bisanyan food fotography digunakan untuk adverting (iklan), Packing, buku menu dan buku masakan. Untuk belajar Food photography bisa dilakukan secara otodidak ataupun melalui lembaga pendidikian jurusan fotografi ataupun tempat kursus [10]. Pemotretan still life adalah menciptakan sebuah gambar dari benda atau objek mati agar tampak jauh lebih hidup dan berbicara, seperti makanan terlihat hangat, dingin, atau lembut [11]. Food photography adalah 
bagian dari still life photography yang digunakan untuk membuat makanan menjadi lebih menarik sehingga orang yang melihat foto tersebut menjadi berselera dan ingin menyicipinya [12].

Food Photography tidak lepas dengan adanya dunia makanan yang menjadi seorang model saat melakukan pengambilan gambar [13]. Jenis makanan yang dihasilkan pun beragam, sehingga food photography juga menjadi usaha bisnis baru yang sangat mendukung usaha kuliner. Kemampuan food photography merupakan Teknik pemasaran produk untuk proses promosi yang lebih baik, yang ditentukan pula oleh faktor unsur permainan cahaya, food stylish, point of interest, unsur menarik perhatian aspek motivasi wirausahawan, aspek unsur usaha dan Teknik pemasaran [14]. Melihat hal ini perlu dibuat pelatihan untuk meningkatkan pengetahuan tentang food photography dan pelatihan itu sendiri kepada pelaku UKM di bidang kuliner yang ada di Kecamatan Rappocini.

\section{METODE}

Pelatihan food photography ini bertujuan untuk memindahkan (transfer) ilmu dan kreatifitas dalam menghasilkan Foto produk-produk pada UKM kuliner yang lebih baik, menarik dan yang lebih berkembang. Terbatas pada pemberian materi pentingnya food photography dan Metode pelaksanaan yang akan digunakan dalam Program Kemitraan Masyarakat (PKM) untuk menemukan solusi adalah Dari segi produksi dan keterbatasan desain foto makanan maupun foto pada kemasan dalam UKM usaha dengan kegiatan Sosialisasi pemberian materi dan Pelatihan. Dari segi pemasaran dengan adanya pelatihan food photography dengan pemakian kamera maupun kamera handphone untuk membantu peningkatan pemasaran dari segi visual hasil UKM kuliner yang ada di Kecamatan Rappocini.

Metode pendekatan yang digunakan untuk mengatasi persoalan yang dihadapi pihak mitra adalah pendekatan partisipasi aktif secara berkelanjutan antara Tim Pengusul dengan pihak mitra. Adapun bentuk partisipasi mitra dalam pelaksanaan PKM adalah menyediakan contoh usaha kuliner, perlengkapan pelatihan, mendampingi dalam proses sosialisasi pemberian mater, memberikan ide/gagasan, pendampingan dan penilaian atas capaian program yang dilaksanakan tim pengusul terhadap mitra dan aktif berinovasi baik dalam pelatihan food photography yang akan diadakan. Bentuk monitoring dilakukan dengan kunjungan lapangan dengan melihat hasil pelatihan yang dilakukan dan juga melakukan monitoring hasil Food fotografi yang mereka buat dengan penggunaan nya untuk pemesaran produk UKM bidang kuliner. Pada saat pemantauan dilakukan kembali upaya upaya yang bisa menumbuhkan kreatifitas dan keahlian untuk mengembangkan usahanya secara jangka panjang dan realisasi perencanaan jangka panjang untuk peningkatan produksi dan kapasitas setelah melakukan pelatihan. Sedangkan bentuk evaluasi dilakukan pada segi desain Food fotografi yang telah dibuat dan pada kelayakan pemasaran.

Adapun tahap pelaksanaan pelatihan food photography adalah sosialisasi mengenai tujuan dan metode pelatihan, penyiapan alat dan bahan, kemudian pemaparan langkah-langkah dalam pembuatan food photography, pelatihan dengan praktek langsung peserta UKM kuliner lalu penilaian aplikasi hasil pelatihan. Adapun alat alat yang dibutuhkan dalam pelatihan adalah alas foto gulung, kamera HP/kamera lensa, karton manila, alas piring, talenan, kain serbet piranti makanan, piranti masak. Sedangkan bahan yang digunakan adalah makanan atau minuman yang akan difoto, serta bahan-bahan yang digunakan dalam pembuatan makanan/minuman.

\section{HASIL DAN PEMBAHASAN}

Pengabdian kepada Masyarakat ini dilaksanakan pada tanggal 14 Oktober 2020 di Aula Emmy Saelan Kantor Kecamatan Rappocini terletak di Jalan Teduh Bersinar Kelurahan Gunung Sari Kecamatan Rappocini Kota Makassar. Kegiatan ini di ikuti oleh 2 perwakilan Kader UKM masing-masing Kelurahan yang ada di Kecamatan Rappocini. Kegiatan ini juga di ikuti dari Kader PKK Kelurahan dan Kecamatan. Kegiatan Pengabdian Kepada Masyarakat ini dimulai dengan pemberian materi tentang Food Photograhy, latar belakang, manfaat dan tujuan dari Pelatihan Food Photography, kemudian materi tentang tata cara pengambilan gambar yang baik dari cahaya, sudut pengambilan atau yang bisa kita kenal dengan angel foto lalu komposisi dan tips untuk setiap makanan yang akan di foto.

Dalam materi food photography terdapat beberapa hal yang perlu diperhatikan, antara lain [15] yaitu tatanan dan peralatan makanan dengan menggunakan food stylish serta memastikan kualitas makanan. Penataan makanan perlu diperhatikan dari sudut pandang kamera, penataan lingkungan dan bahan-bahan yang digunakan harus terlihat segar dan bersih, selanjutnya mengikuti naluri, tips dan trik penataan dimana dengan menambahkan volume, hiasan makanan, menjaga tetap nyata, menaruh di atas es, dan penggunaan uap serta penataan dan perlengkapan dengan pemilihan tema yang tepat dan penggunaan aksesoris yang sesuai serta alas/background yang bertekstur dan tekstil yang digunakan. 

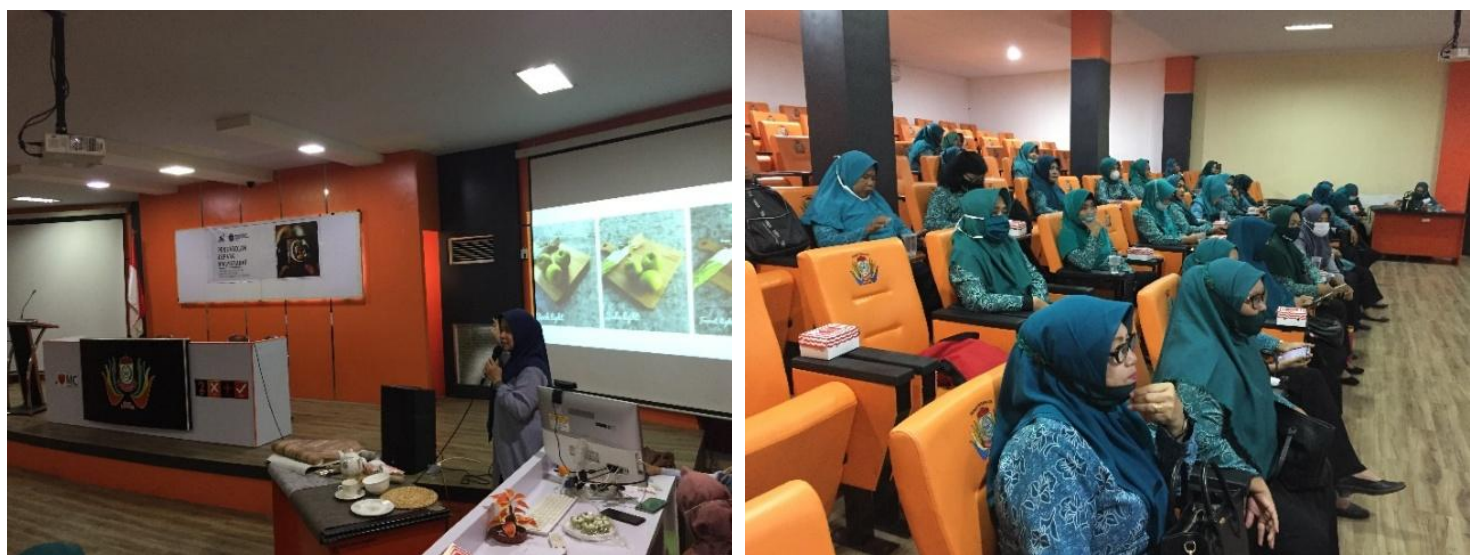

Gambar 3. Pemberian materi kepada Peserta

(Sumber : dokumentasi pribadi)

Sebelum penyajian materi para peserta diberikan informasi alat dan bahan apa yang bisa digunakan seperti alat makan, talenan, alas foto, alas piring, dan lain sebagainya. Dalam pemberian materi pelatihan ini dipaparkan tentang pencahayaan, Sumber cahaya paling mudah dan murah adalah cahaya matahari, bisa melalui jendela, pintu kaca, atau jika kita melakukan pemotretan outdoor (natural light). Permainan lighting sangat menentukan mood foto. Teknik pencahayaan low key dalam food photography menjadi hal penting karena fokus pada tekstur makanan dan juga dibutuhkan food stylish untuk menciptakan bentuk makanan yang indah dan penuh selera [16]. Pencahayaan terbaik yang bisa digunakan tanpa menggunakan pencahayaan tambahan yaitu di tempat terbuka seperti teras rumah, di jam terbaik dan pengambilan cahaya dari belakang depan ataupun samping. Dari sisi objek foto, cahaya dari samping objek akan membuat tekstur terlihat tiga dimensi, menciptakan kedalaman, dan dramatisasi [17].

Untuk materi mengenai angel foto di jelaskan 3 macam sudut pengambilan foto yang sering digunakan yaitu flat lay pengambilan dari atas membentuk 90 derajat,high level dan eye level. Kemudian dilanjutkan dengan Komposisi pengaturan makanan dijelaskan ada 3 pengaturan komposisi yaitu center,figure to ground dan segitiga. Komposisi fotografi adalah masalah menempatkan berbagai benda yang terpotret dalam bingkai foto. Pengambilan gambar yang dilakukan fotografer bergantung pada kualitas lensa, cara memposisikan angle atau posisi arah kamera, panel pada kamera dan kecanggihan sebuah lensa [18]. Dari Pemberian materi pelatihan ini peserta sudah bisa mengerti dan memahami dalam hal Food Photography sehingga disaat pelatihan langsung mereka dapat menerapkan materi yang telah diberikan.

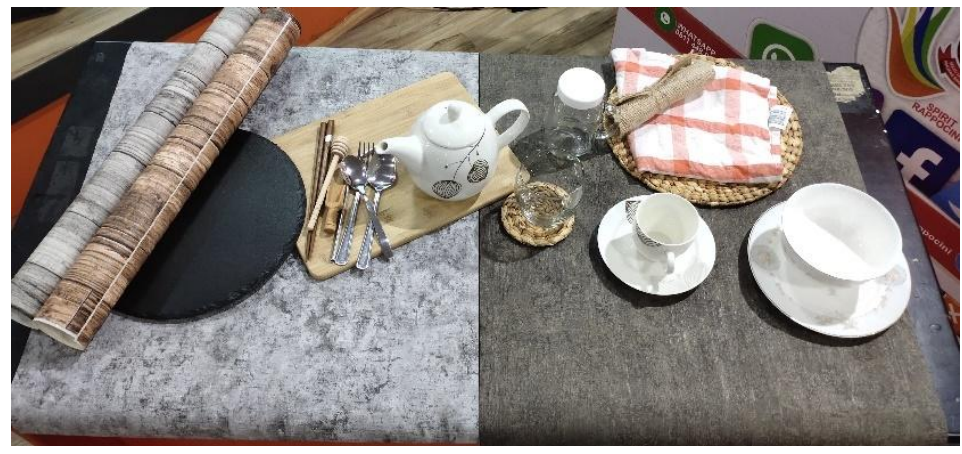

Gambar 4. Alat dan bahan yang digunakan

(Sumber : dokumentasi pribadi)

Kegiatan selanjutnya adalah pengaplikasian materi yang telah diberikan dengan mencoba memotret makanan yang telah disediakan. Makanan yang disediakan yaitu kue tradisonal, minuman dan juga makanan. Ketiga makanan ini mewakili dari ragam UKM kuliner yang ada di Kecamatan Rappocini. Para peserta menggunakan kamera hanphone mereka dan langsung mencoba memotret ketiga makanan tersebut dan dikoreksi dari hasil-hasil gambar yang mereka buat. Sehingga para peserta lebih memahami bagian-bagian yang salah maupun yang benar dalam menghasilkan gambar makanan yang mereka akan buat nantinya. Melalui pelaksanaan kegiatan ini sasaran yang diharapkan terlihat jelas perubahan dalam aspek penyajian makanan dan Food Photography yang dihasilkan oleh UKM Kuliner yang ada di Kecamatan rappocini untuk meningkatkan pemasaran mereka. 


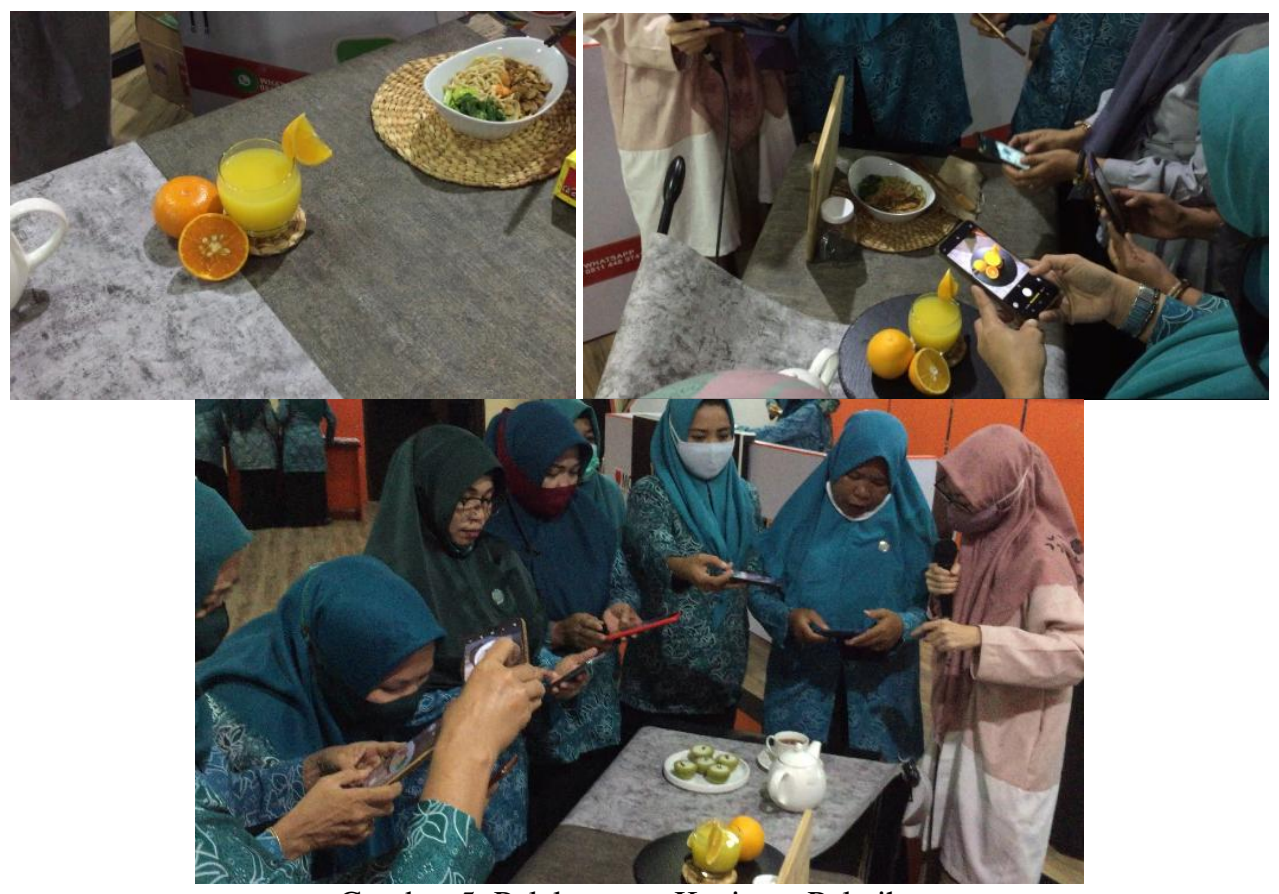

Gambar 5. Pelaksanaan Kegiatan Pelatihan

(Sumber : dokumentasi pribadi)

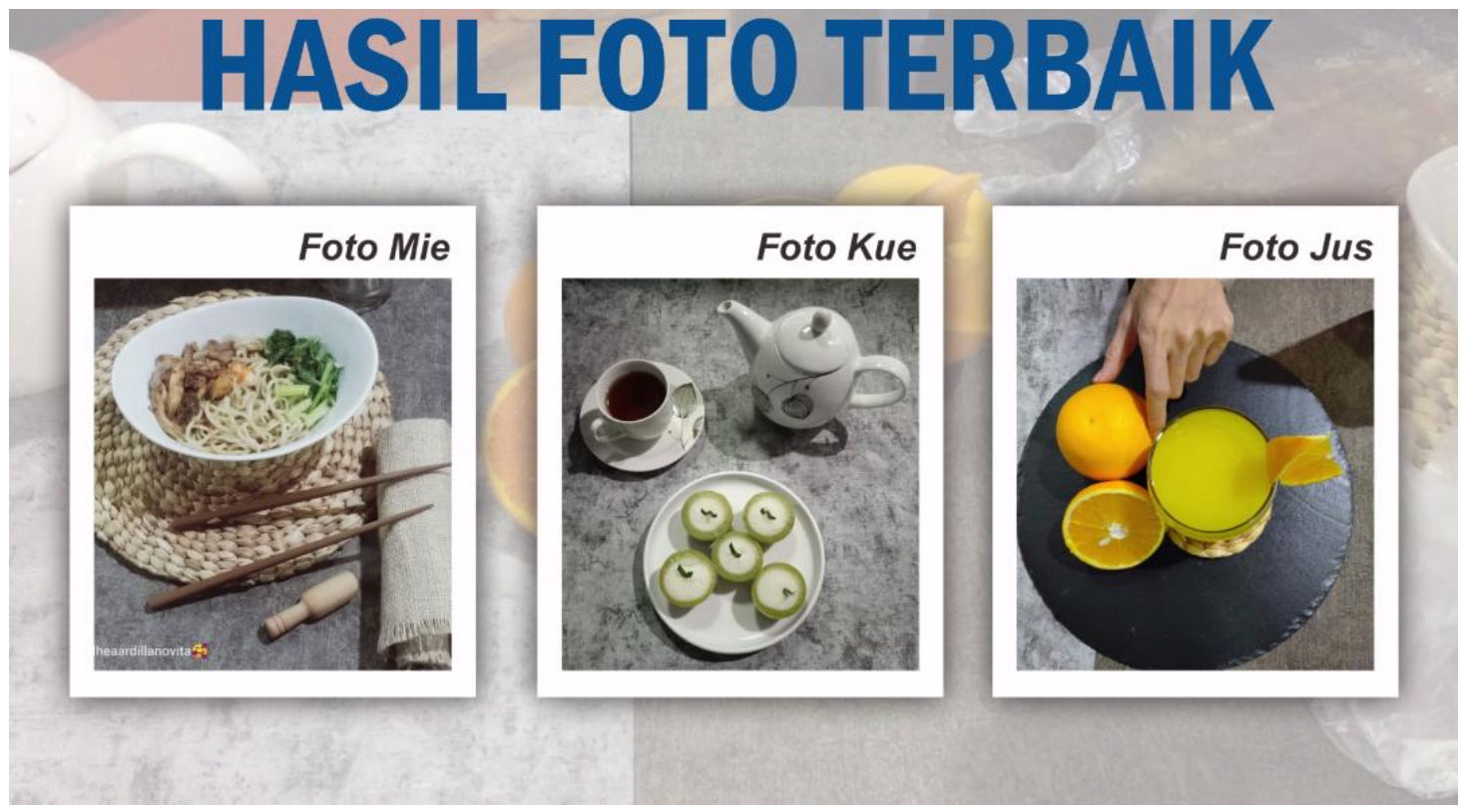

Gambar 6. Hasil Foto Terbaik dari peserta

(Sumber : dokumentasi pribadi)

Pada gambar diatas terdapat 3 hasil foto terbaik para peserta pelatihan dengan tiga makanan yang berbeda. Dari hasil foto ini kita dapat lihat bahwa para peserta yang tadinya tidak mengerti sama sekali dengan food photography, apa manfaat dan Bagaimana menghasilkan foto makanan yang menarik dengan adanya pelatihan ini mereka dapat menghasilkan foto makanan yang menarik dan menggugah selera. Sehingga para peserta pelatihan ini sudah bisa menerapkan untuk UKM Kuliner mereka.

Dari beberapa penjelasan tersebut di atas kegiatan pelatihan food fotography bagi UKM Kuliner secara rinci dapat dilihat dalam diagram fish bone berikut. 


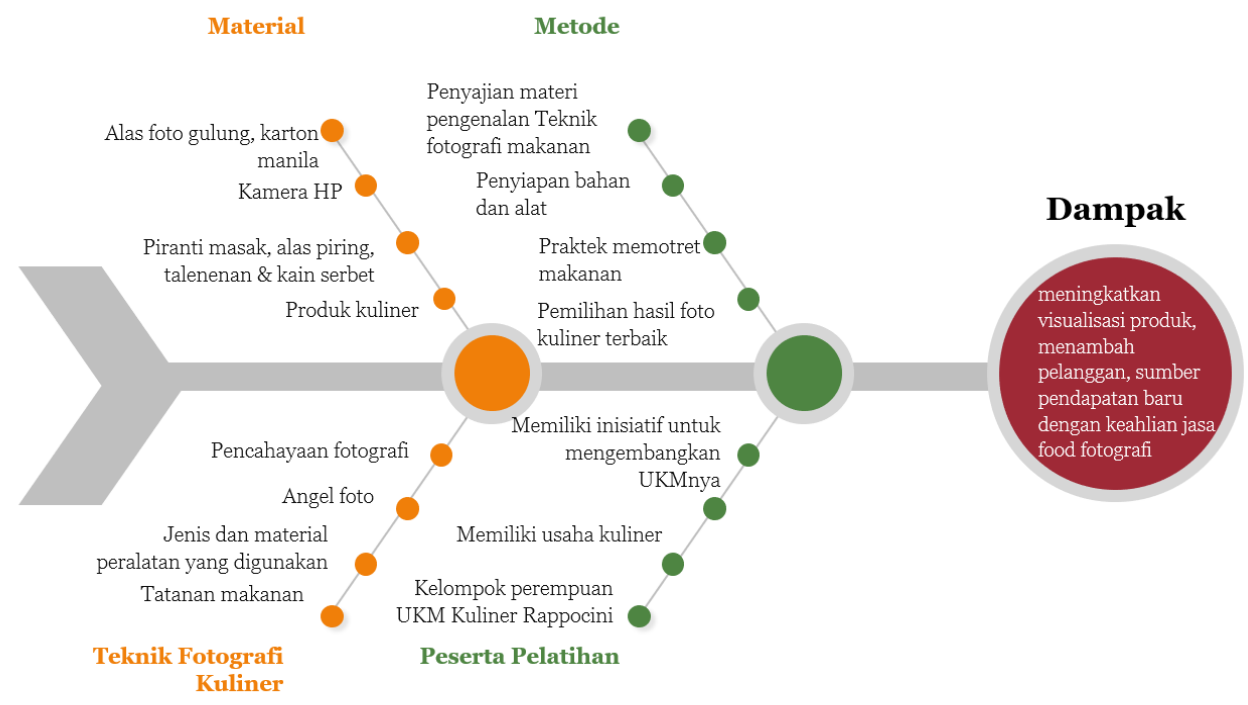

Gambar 7. Diagram Fish Bone Dampak Pelatihan Food Fotography

(Sumber : Hasil Analisis, 2020)

Dalam pemberian Materi Food Photography dilakukansemudah mungkin dalam penggunaan bahasa dan juga teknik sehingga peserta dengan mudah mengerti dengan materi, para peserta diberikan kesempatan bertanya dan diberikan pengarahan secara langsung pada saat pelatihan berlangsung sehingga peserta dapat mengetahui yang menjadi kekurangan ataupun kelebihan dari foto yang masing- masing peserta buat. Selain itu, peserta dapat langsung mengambil gambar dengan objek makanan yang disediakan. Namun kelemahannya, pada saat pelatihan ini karena dilakukan di dalam ruangan yang menggunakan sumber pencahayaan buatan yaitu lampu biasa. Sehingga peserta tidak maksimal dari sumber cahaya alami menyebabkan sering terjadi distorsi cahaya atau bayangan yang dapat mengurangi kualitas foto.

Kegiatan pelatihan ini ke depannya memberi dampak diantaranya apabila para peserta terus menerus mencoba dalam hal food photography dan berlatih akan menambah keahlian yang tidak hanya dapat meningkatkan pemasaran kuliner itu sendiri tetapi juga menjadi sumber pendapatan lain seperti membuka jasa food photography. Namun, para peserta terlalu cepat puas dengan hasil gambar yang didapat sehingga kurang maksimal karena food photography sebaiknya harus banyak berlatih, melihat ilmu dan referensi yang ada.

\section{KESIMPULAN}

Dalam Pemasaran sebuah produk Kuliner dibutuhkan penyajian makanan yang baik dan juga Foto makanan yang menarik sehingga pelatihan Food Photography ini sangat membantu meningkatkan usaha Ukm yang ada di kecamatan rappocini khususnya yang bergerak di bidang kuliner. Peningkatan pemahaman dan keterampilan dari ukm Kuliner yang ada di Kecamatan Rappocini juga bertambah. Para pelaku Ukm sangat antusias dan merasakan manfaat dengan adanya pelatihan ini sehingga foto makanan yang mereka tampilkan tidak lagi mereka ambil dari internet tetapi mereka dapat mengambil langsung gambar makanan atau minuman yang mereka pasarkan.

\section{DAFTAR PUSTAKA}

[1] EE. Wati, Persepsi Para Pelaku UKM (Usaha Kecil Dan menengah) terhadap Penerapan Akuntansi,” Skripsi Sekolah Tinggi Ilmu Ekonomi Perbanas Surabaya. 2011.

[2] F. Kuswantoro, MM. Rosli, RA Kader, "Innovation in Distribution Channel, Cost Efficiency \& Firm Performance: The Case of Indonesian Small \& Medium Enterprise Scales," International Journal of Business, Humanities and Technology, vol. 2, no. 4, p. 23-38. 2012

[3] I. Rochmawati, "Kualitas Visual \& Respresentasi Foto Makanan Kuliner Bandung di Instagram, "Jurnal Artic, vol. 1, p.1-12. 2018

[4] T. Alwi \& E. Handayani, E, "Keunggulan Bersaing UKM yang dipengaruhi oleh Orientasi Pasar dan Inovasi Produk, Jurnal Pengembangan Wiraswasta," vol.2, no.3, p. 193-202.

[5] FB. Albar, A. Wisudianto, GF. Mubiena, A. Mansur, "Desain Strategi Pengembangan UKM dengan Kombinasi Metode Benchmarking dan Blue Ocean Strategy," Seminar Nasional IENACO, pp. 555-562. 2014.

[6] Siswanto, "Food Photography Sebagai Media Promosi Dalam Media Cetak", Jurnal Saraswati ISI Yogyakarta, https://doi.org/10.24821/srs.v0i0.557

[7] JA Sutanto, BS. Banindro, YH Yulianto, "Perancangan Fotografi Makanan Tradisional Makassar "Sedap Mentong Makanang Makassar,” Jurnal DKV Adiwarna Universitas Kristian Petra, vol. 1, no. 14, p. 1-8. 2019. 
[8] YS. Purwanto, M. Veranita, "Pelatihan Fotografi Dasar Bagi Pelaku Usaha Kecil dan Menengah (UKM) Kecamatan Lengkong Kota Bandung," Jurnal Dharma Bakti Ekuitas, vol. 2, no. 2, p. 205-211. 2018.

[9] R. Ambarsari, "Food Photography For Everyone," Elex Media Komputindo Jakarta. 2013

[10] DS. Indra, "Food Fotografi Tutorial," Elex Media Kumputindo Jakarta. 2013.

[11] WD. Indriyani, "Karakteristik Fotografi Still Life Karya Nofria Doni Fitri," Skripsi Program Studi Pendidikan Seni Rupa Fakultas Bahasa dan Seni, Universitas Negeri Yogyakarta. 2016.

[12] NI Vita, FA Putri, "FOOD PHOTOGRAPHY (Analisis Semiotik Food Photography Yang Menampilkan Kuliner Kota Medan Dalam Rubrik Appetite Aplaus Magazine Edisi Desember 2015)," Prosiding Seminar Nasional Komunikasi 2016, p. 55-67. 2016.

[13] IRP. Putra, M. Bahruddin, TH. Dewanto, "Pembuatan Buku Fotografi Makanan (Studi Kasus Obyek Wisata Jawa Timur,” Jurnal Desain Komunikasi Visual, vol.1, no.1, p. 50-56. 2013

[14] D. Evawati, RC. Rosyidasari, "Kemampuan Food Photography terhadap Peningkatan Berwirausaha dan Omzet Penjualan Produk Kuliner," Prociding CEBA 2018, Budaya Bisnis Berbasis Ekonomi Hijau di Era Industri 4.0, Universitas PGRI Adi Buana Surabaya, p. 214-223. 2018.

[15] K. Nisak, D. Hariyanto, "Food Photography \& Eating Out di Media Sosial Instagram," Kanal Jurnal Ilmu Komunikasi Universitas Muhammadiyah Sidoarjo, vol. 6, no. 1, p. 31-40. 2017.

[16] RR. Puggaan, "Pembuatan Makanan Khas Jambi dengan Teknik Low Key dalam Food Photography," Program Studi S1 Fotografi Jurusan S1 Fotografi Fakultas Seni Media Rekam, Institut Seni Indonesia Yogyakarta. 2017.

[17] R. Ambarsari, "Motret Makanan itu Gampang," PT Elex Media Komputindo Jakarta. 2015

[18] N. Pratiwi, "Teknik Memotret Alam Bebas untuk Meningkatkan Daya Tarik Traveling," Skripsi Program Studi Ilmu Sosial dan Ilmu Politik Universitas Muhammadiyah Sumatera Utara Medan. 2019. 